\title{
Performance evaluation of commercial maize hybrids across diverse Terai environments during the winter season in Nepal
}

\author{
Mahendra Prasad Tripathi*, Jiban Shrestha, and Dil Bahadur Gurung \\ ${ }^{1}$ Nepal Agricultural Research Council \\ National Maize Research Program, Rampur, Chitwan, Nepal \\ *Corresponding author email: mptripathi@gmail.com
}

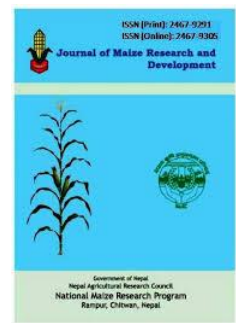

Received: September 2016; Revised: October 2016; Accepted: November 2016

\begin{abstract}
The hybrid maize cultivars of multinational seed companies are gradually being popular among the farmers in Nepal. This paper reports on research finding of 117 maize hybrids of 20 seed companies assessed for grain yield and other traits at three sites in winter season of 2011 and 2012. The objective of the study was to identify superior maize hybrids suitable for winter time planting in eastern, central and inner Terai of Nepal. Across site analysis of variance revealed that highly significant effect of genotype and genotype $\times$ environment interaction (GEI) on grain yield of commercial hybrids. Overall, 47 genotypes of 16 seed companies identified as high yielding and stable based on superiority measures. The statistical analysis ranked topmost three genotypes among tested hybrids as P3856 (10515 $\left.\mathrm{kg} \mathrm{ha}^{-1}\right)$, Bisco prince $\left(8763 \mathrm{~kg} \mathrm{ha}^{-1}\right)$ as well as Shaktiman $\left(8654 \mathrm{~kg} \mathrm{ha}^{-1}\right)$ in the first year; and $3022\left(8378 \mathrm{~kg} \mathrm{ha}^{-1}\right)$, Kirtiman manik (8323 $\mathrm{kg} \mathrm{ha}^{-}$ $\left.{ }^{1}\right)$ as well as Top class $\left(7996 \mathrm{~kg} \mathrm{ha}^{-1}\right)$ in the second year. It can be concluded that stable and good performing hybrids identified as potential commercial hybrids for general cultivation on similar environments in Nepal.
\end{abstract}

Keywords: Genotype grouping, $\mathrm{G} \times \mathrm{E}$ interaction (GEI), grain yield, hybrid maize, superiority measure

Correct citation: Tripathi, M.P., Shrestha, J., \& Gurung, D.B. (2016). Performance evaluation of commercial maize hybrids across diverse Terai environments during the winter season in Nepal. Journal of Maize Research and Development, 2 (1):1-12, doi: http://dx.doi.org/10.3126/jmrd.v2i1.16210

\section{INTRODUCTION}

Maize (Zea mays L.) is the key ingredient for poultry and livestock ration in addition to its position as one of the major food crop in Nepal (Dhakal et al., 2015). It has a wider range of uses as compared other cereal as food, feed, fuel, fodder, and industrial raw materials. The changing consumer habits from starch to protein rich food demanded more amounts of animalderived foodstuff in the country. In the meantime, ever increasing trend of poultry and livestock business along with increasing population and rising income has demanded more amounts of maize grains. A current market requirement of maize grains is partly fulfilled by growing hybrids 
in winter at Terai and inner Terai (Gurung et al., 2011). Because of higher yield potentiality and assurance market of maize grains, farmers' attraction towards hybrids cultivar increased radically on these days. Yield advantage of hybrid cultivar over traditional variety is a critical component for determining the attraction towards hybrid maize (Heisey et al., 1998). In Nepal, farmers started to grow hybrid maize since 1980s by importing seeds from India due to the open border between the countries (Thapa, 2013). It has already covered approximately 80 and 10 percent of maize production respectively in Terai and mid hills (Adhikari, 2014). Hybrid maize concealed around seven to ten percent area of Nepal in 2010 (Gurung et al., 2011; Thapa, 2013) and area under hybrid maize is increasing every year. Nepal imports almost 20 percent of corn seeds every year (Adhikari, 2014) and nearly 100 percent of hybrid seed is being imported from India (Gurung et al., 2011). Hence, it can be projected that hybrid maize covered around 12-15\% maize area in Nepal. Due to increasing investment of government and private sector on hybrid maize seed, it covered around 90\% percent area under winter maize. However, nearly 40-45 percent of maize grains used in feed industries are being still imported from India every year (CDD, 2013). It is minimum possibility for maize area expansion in the mid hills because agricultural land has already been exhausted in Nepal (Ransom et al., 2003). However, it is still scope for increasing cropping intensity in Terai, inner Terai and foot-hills (e.g., rice-fallow systems) by growing hybrid maize in winter. The increment of winter maize area by two folds under hybrid in Terai may help to reduce current trade imbalance of the country. Unfortunately, few hybrids developed from national research system and those released are not competitive. First of all, the grain yield performance of released cultivar is low as compared to commercial hybrids and secondly, seed availability of those hybrids is almost negligible for general cultivation. Unavailability of competitive hybrid cultivars within the country and underdeveloped seed industries caused dependency over imported hybrid maize seed every year (Gurung et al., 2011). Large numbers of multinational companies' hybrids have been registered in National Seed Board in Nepal. In this context, as the hybrid maize area has been growing extensively in Terai and partly in mid-hill districts, the commercial seed companies are the major source of seed. Hybrid maize seed marketing is flourishing every year but limited commercial hybrids are suited to cultivation owing to existing diverse agro-ecological regime of the country. Therefore, the objective of this study was to identify superior maize hybrids suitable for winter time planting in eastern, central and inner Terai of Nepal.

\section{MATERIALS AND METHODS}

\section{Commercial hybrid maize evaluation trial dataset}

Hybrid maize of various commercial seed companies was being evaluated regularly in across sites coordinated trials by National Maize Research Program, Rampur since 2010/11. This experiment was conducted at three sites i.e. Rampur, Chitwan (Inner Terai), Parwanipur, Bara (Central Terai) and Tarahara, Sunsari (Eastern Terai) during winter seasons of 2010/11 and 2011/12. These are the representative sites where winter maize is extensively cultivated in winter season in Nepal. Sixty-nine hybrids of 12 seed companies and 56 hybrids of 12 seed companies were evaluated on multi-location trial in the first and second year respectively. Seven varieties from Monsanto and four seed companies were common in both the years. Therefore, altogether 
Journal of Maize Research and Development (2016) 2 (1): 1-12

ISSN: 2467-9291 (Print), 2467-9305 (Online)

DOI: http://dx.doi.org/10.3126/jmrd.v2i1.16210

117 hybrids of 20 seed companies were evaluated in the period of two years. A detail list of the materials with respective companies is presented in table 1-2.

Table 1. List of genotypes with respect to seed company used in the multi-location trial during November 2010 to April 2011.

\begin{tabular}{|c|c|}
\hline Seed Companies & ds name \\
\hline $\begin{array}{l}\text { Aishwarya Seeds India Private Limited, } \\
\text { Hyderabad, India }\end{array}$ & $\begin{array}{l}\text { Aditya-929, } \quad \text { Challenge-1, } \quad \text { Early-2, } \\
\text { Kesherking-919, Madhur, TCS-9696 }\end{array}$ \\
\hline $\begin{array}{l}\text { Bisco Bio-science Pvt. Ltd., Hyderabad, } \\
\text { India }\end{array}$ & $\begin{array}{l}\text { Bisco Bumper, Bisco Heera, Bisco Prince, Bisco x 81, } \\
\text { Bisco x 92, Bisco x } 97 \text { Gold, Naya } 940\end{array}$ \\
\hline Bayer Bio-science Hyderabad, India & $\begin{array}{l}\text { ro-4640, Proagro-4642, Proagro- } \\
\text { a }\end{array}$ \\
\hline Charoen Pokphand Seed & , CP-838, \\
\hline elt & $\sqrt{ } 20$, \\
\hline t Ltd & $\begin{array}{l}\text { DMH-7314, DMH-849, MM-1107, MM-1109, MM- } \\
7705\end{array}$ \\
\hline Monsantc & $\begin{array}{l}900 \text { M Gold, All-rounder, Pinnacle, Dekalb-Double, } \\
\text { Prabal, DKC 9081, Super -900M, Hi-shell, Dekalb DK- } \\
984\end{array}$ \\
\hline & 33 \\
\hline Nuzi & $\begin{array}{l}\text { lhya), NMH -777 (Sunny), } \\
09\end{array}$ \\
\hline or & 4, P 3522, P 3540, P 3785, P3856 \\
\hline $\begin{array}{l}\text { Shree Ram Bio-seed Genetics India, Pvt., } \\
\text { Hyderabad }\end{array}$ & $\begin{array}{l}\text { 9220, 9681, Badshah Gold, Commando, Rajkumar, } \\
\text { Shaktiman, Tx-369 }\end{array}$ \\
\hline Zuari Seed India Ltd., Hyderabad, India & C-1921, C-1945, C-1946, C-1950, C-6485 \\
\hline
\end{tabular}

The crop planted in $2^{\text {nd }}$ and $3^{\text {rd }}$ week of November respectively in 2010 and 2011 . The experiment was conducted in Randomized Complete Block (RCB) design with two replicates in each site on both the years. Each experimental plot had four rows of $5 \mathrm{~m}$ long, with $0.75 \mathrm{~m}$ an inter-row spacing and $0.25 \mathrm{~m}$ intra-row spacing.. NPK was applied as fertilizer @ $160 \mathrm{~kg} \mathrm{~N}, 60$ $\mathrm{kg} \mathrm{P}_{2} \mathrm{O}_{5}$ and $40 \mathrm{~kg} \mathrm{~K}_{2} \mathrm{O} \mathrm{ha}^{-1}$ in the form of urea, di-ammonium phosphate (DAP), and Murate of Potash (MoP). A total dose of phosphorus and potash applied as basal dose but urea was added on three splits; the first $1 / 2$ at planting time, next $1 / 4$ and later $1 / 4$ at four weeks and six weeks after planting respectively. Furthermore, farm yard manure $\left(10 \mathrm{t} \mathrm{ha}^{-1}\right)$ also incorporated in soil at the time of land preparation.

\section{Data recording and statistical analysis}

The observation recorded for grain yield (considering 0.8 standard shelling co-efficient along with 12.5 percent adjusted grain moisture before converting $\mathrm{kg}$ per hectare), days silking (days after planting when half of the plants extrude silks). Plant height measured before harvesting by using measuring scale. The grain yield was estimated using formula adopted by MacRobert et al. (2014). 
Journal of Maize Research and Development (2016) 2 (1): 1-12

ISSN: 2467-9291 (Print), 2467-9305 (Online)

DOI: http://dx.doi.org/10.3126/jmrd.v2i1.16210

$$
\text { Grain yield }\left(\frac{\mathrm{kg}}{\mathrm{ha}}\right)=\frac{\text { Fresh ear weight } \times(100-\mathrm{MC}) \times 0.8 \times 10,000}{(100-12.5) \times 7.5}
$$

Where, $\mathrm{MC}=$ harvest time moisture content in grains $(\%), 0.8=$ standard shelling co-efficient, $12.5=$ standard moisture content, and $7.5=$ area harvested $\left(\mathrm{m}^{2}\right)$

All agronomic traits were analyzed using META-R software for both specific and across-site analysis (Alvarado et al., 2015). The variance due to genotype, genotype $\times$ environment interaction, and environment calculated to estimate broad sense heritability.

The per se genotypic mean grain yield ranked to assess the status of cross over GEI. Superiority index (Pi) value calculated for the rank of grain yield based on the model proposed by Lin and Binns (1988) to identify good performing and stable genotypes. The genotypes with lowest Pi value and most productive in a given set of environments were considered as superior (Lin and Binns, 1988; Ye et al., 2001).

$\mathrm{P}_{\mathrm{i}}=\sum_{\mathrm{j}=1}^{\mathrm{s}}\left(\mathrm{y}_{\mathrm{ij}}-\mathrm{y}_{\mathrm{mj}}\right)^{2} / 2 \mathrm{vWhere}, \mathrm{Pi}=$ superiority index in which the smaller the value the better the genotype, yij $=$ yield of $i^{\text {th }}$ genotype in the $j^{\text {th }}$ site, $y m j=$ maximum response among the genotypes in the $\mathrm{j}^{\text {th }}$ site, $\mathrm{v}=$ numbers of genotypes.

Table 2: List of genotypes with respect to seed company used in the multi-location trial during November 2011 to April 2012.

\begin{tabular}{|c|c|}
\hline \multirow{2}{*}{$\begin{array}{l}\text { Seed Companies } \\
\text { Advanta Seeds }\end{array}$} & Hybrids \\
\hline & $\begin{array}{l}\text { PAC-740, PAC-745, PAC-746, PAC-999, Premire, Scorpio, } \\
\text { Challenger }\end{array}$ \\
\hline Bio-science & Bisco Jambo-65 and Bisco Moti Delux \\
\hline Hyderabad, India & \\
\hline $\begin{array}{l}\text { Chand Hybrid Seeds Company } \\
\text { Hyderabad, India. }\end{array}$ & 907, C-745, Top-Sheel 957, 951 Supe, SC 719 \\
\hline $\begin{array}{l}\text { Sichuan Deyue Technology Seed Industry } \\
\text { Co.. Ltd. China }\end{array}$ & JM-1, JM-2, JM-3, JM-4, JM-5, JM-6, JM-7 \\
\hline Dhaanya Seeds Pvt Ltd & DHM-8255, MM-7529, MM-7659 \\
\hline $\begin{array}{l}\text { Kirtiman Agro } \quad \text { Genetics } \\
\text { Aurangabad, India }\end{array}$ & $\begin{array}{l}\text { Kritiman Manik, Kritiman Nares, Saurav Round, Tanishk, } \\
\text { Saurav Flat, Kirtiman Kundan }\end{array}$ \\
\hline Monsanto India Ltd. Mumbai, India & $\begin{array}{l}\text { 900M -Gold, All-rounder, Pinnacle, Dekald-Double, Prabal, } \\
\text { DKC-9081, Super -900M, DKC-9120, }\end{array}$ \\
\hline Manisha Agri Biotech Pvt Ltd., & Manisa-6363, Manisa-7272, Manisa-9292, Manisa-8181 \\
\hline Pioneer HI Seeds Ltd., Hyderabad, India & P-3396 \\
\hline Rasi Seeds Pvt. Ltd. India & Tip-Top, Top-Class, 3022, 3033 \\
\hline South East Asia | Namdhari Seeds Pvt. & Bikas-666, Unnati-555 (Pragati) \\
\hline Vibha Agrotech Ltd., India & $\begin{array}{l}\text { Boom (VMH-2015), Elite (VMH-2009), Legend, Eden-4040, } \\
\text { Super-High-Corn (VMH-2000), MAC (VMH-4102), X-Paid }\end{array}$ \\
\hline
\end{tabular}

\section{RESULTS}

\section{Analysis of variance in maize performance}

The days to silking ranged from 113-127 with mean 119 days in the first year and 108123 days with mean 116 in next year (Table 3-4). It indicated that days to flowering differed by two weeks between the early and late genotypes so that maturity period differs by one month 
between the early and late maturing genotypes. The plant height ranged from 153-222 with mean $187 \mathrm{~cm}$ in 2010-11 whereas it ranges from 149-189 with mean $173 \mathrm{~cm}$ in 2011-12 (Table 3-4). The highest plant height observed on 30B11 followed by P3856 in the first year. Then, Top class and Kirtiman Kundan respectively observed as tall and dwarf variety in the corresponding year.

Table 3: Variation and analysis of variance for silking days, plant height and yield for top and bottom five yield performing genotypes across locations in 2010/11.

\begin{tabular}{|c|c|c|c|c|c|c|}
\hline \multirow[t]{2}{*}{ Genotypes } & \multirow{2}{*}{$\begin{array}{c}\begin{array}{c}\text { Silking } \\
\text { days }\end{array} \\
\text { ding }\end{array}$} & \multirow{2}{*}{$\begin{array}{l}\text { Plant height } \\
\text { (cm) }\end{array}$} & \multicolumn{4}{|c|}{ Grain yield $\mathrm{kg} \mathrm{ha}^{-1}$} \\
\hline & & & Parwanipur & Rampur & Tarahara & Mean \\
\hline Bisco-X97-Gold & 123 & 188 & 7218 & 11704 & 9368 & 10536 \\
\hline P-3856 & 124 & 216 & 9546 & 11490 & 9541 & 10515 \\
\hline 30B11 & 127 & 222 & 6869 & 9872 & 10345 & 10108 \\
\hline C-1946 & 117 & 184 & 7903 & 8538 & 11654 & 10096 \\
\hline NMH-666 & 116 & 203 & 6586 & 8016 & 12119 & 10067 \\
\hline CP-828 & 124 & 201 & 8442 & 6528 & 5622 & 6075 \\
\hline $10 \mathrm{~V} 10$ & 116 & 200 & 8541 & 3502 & 8494 & 5998 \\
\hline DMH-849 & 113 & 153 & 8623 & 5557 & 5497 & 5527 \\
\hline Dekalb-Double & 118 & 174 & 8041 & 4190 & 6506 & 5348 \\
\hline Madhur & 123 & 177 & 9361 & 3699 & 5332 & 4515 \\
\hline Grand Mean & 119 & 187 & 8368 & 7464 & 8102 & 7783 \\
\hline Maximum & 127 & 222 & 10713 & 9665 & 10134 & 10536 \\
\hline Minimum & 113 & 153 & 4824 & 5407 & 6364 & 4515 \\
\hline Heritability & 0.761 & 0.518 & 0.00 & 0.52 & 0.51 & 0.25 \\
\hline Genotype & 8.485 & 107.52 & 0.0 & 1838573 & 1221799 & 425276 \\
\hline Gen $\times$ & 5.261 & 141.05 & - & - & - & 1104909 \\
\hline Residual & 5.424 & 317.42 & 3041417 & 3404497 & 2386758 & 2895628 \\
\hline $\mathrm{LSD}_{005}$ & 2.66 & 20.34 & 3820 & 3682 & 3083 & 2401 \\
\hline $\mathrm{CV}, \%$ & 1.96 & 9.53 & 20.84 & 24.72 & 19.07 & 22.00 \\
\hline
\end{tabular}

Table 4: Variation and analysis of variance for silking days, plant height and yield for top and bottom five yield performing genotypes across locations in 2011/12.

\begin{tabular}{lcccccc}
\hline Genotypes & Silking & Plant height & \multicolumn{4}{c}{ Grain yield $\mathrm{kg} \mathrm{ha}^{-1}$} \\
\cline { 4 - 6 } & days & $(\mathrm{cm})$ & Parwanipur & Rampur & Tarahara & Mean \\
\hline 3022 & 119 & 178 & 9322 & 7370 & 8442 & 8378 \\
Kirtiman-Manik & 116 & 152 & 8100 & 7304 & 9567 & 8323 \\
P-3396 & 112 & 175 & 9875 & 8120 & 6217 & 8070 \\
Top-Class & 115 & 189 & 8260 & 7957 & 7772 & 7996 \\
MAC-(VMH-4102) & 114 & 159 & 7717 & 8202 & 7523 & 7814 \\
Pragati & 108 & 173 & 5860 & 2862 & 3513 & 4078 \\
SC-719 & 123 & 172 & 3494 & 5246 & 3093 & 3944 \\
907 & 114 & 179 & 4394 & 3708 & 3562 & 3888 \\
JM-5 & 111 & 170 & 5646 & 1305 & 4711 & 3887 \\
Kirtiman-Kundan & 119 & 149 & 3902 & 2916 & 3733 & 3517 \\
\hline Grand Mean & 116 & 173 & 6552 & 5474 & 6118 & 6048 \\
Maximum & 123 & 189 & 9875 & 8202 & 9567 & 8323 \\
Minimum & 108 & 149 & 3334 & 1305 & 2043 & 3517 \\
Heritability & 0.70 & 0.650 & 0.846 & 0.760 & 0.460 & 0.560 \\
Genotype variance & 13.51 & 105.96 & 2624867 & 1610035 & 1424657 & 812554 \\
Gen $\times$ Loc variance & 9.75 & 28.31 & - & - & - & 1073966 \\
Residual & 15.33 & 291.02 & 954270 & 1019346 & 3286235 & 1753284 \\
LSD $_{0.05}$ & 4.48 & 20 & 1958 & 2023 & 3632.9 & 1515 \\
CV, \% & 3.4 & 9.9 & 14.91 & 18.45 & 29.6 & 21.9 \\
\hline
\end{tabular}




\section{Journal of Maize Research and Development (2016) 2 (1): 1-12 \\ ISSN: 2467-9291 (Print), 2467-9305 (Online) \\ DOI: http://dx.doi.org/10.3126/jmrd.v2i1.16210}

Likewise, the five top yielding genotypes produced more than $10000 \mathrm{~kg} \mathrm{ha}^{-1}$ grain yields but lowest five provided $4515-6364 \mathrm{~kg} \mathrm{ha}^{-1}$ with trial mean yield $7783 \mathrm{~kg} \mathrm{ha}^{-1}$ in $2010-11$. On the other hand, top five genotypes provided $7814-8378 \mathrm{~kg} \mathrm{ha}^{-1}$ and lowest five gave $3517-4078 \mathrm{~kg}$ $\mathrm{ha}^{-1}$ with trial mean $6048 \mathrm{~kg} \mathrm{ha}^{-1}$ in 2011-12. High yielding genotype produced more than 35 to 38 percent higher than average grain yield in the first year and second year respectively. It also indicated that the lowest yielding genotype has produced nearly 50 percent greater yield than the national average $\left(2501 \mathrm{~kg} \mathrm{ha}^{-1}\right)$ of 2012. The results from analysis of variance revealed that the effect of GEI on grain yield was highly significant with the relatively greater proportion of total variation contributed by GEI in both the years. In the meantime, a large yield variation explained by environments and GEI than genotype. It indicates that environment and GEI effect was more important for grain yield in hybrid maize.

\section{Genotype grouping based on ranking}

Four distinct groups of genotypes observed in both the years when mean rank plotted against the Francis coefficient of variation (Table 5). The mean rank 34.5 and coefficient of variation (CV) 40 percent in table 5 as well as the mean, rank 28 and Francis CV 42 percent in table 6 divided the graphs into four quadrants. It makes easy to understand the distribution pattern of genotypes in a simple and descriptive way.

Table 5. Genotype grouping based on coefficient of variation vs rank mean yield from 2010-11 data

\begin{tabular}{|c|c|c|c|c|}
\hline Seed companies & Group I (11) & Group II (25) & Group III (15) & Group IV (18) \\
\hline $\begin{array}{l}\text { Aishwarya Seeds } \\
\text { India (7)* }\end{array}$ & - & TCS-9696 (1) & Godavari-989 (1) & $\begin{array}{l}\text { Aditya- } \\
\text { 929,Challenge- } \\
\text { 1,Early-2, } \\
\text { Kesherking-919, } \\
\text { Madhur (5) }\end{array}$ \\
\hline $\begin{array}{l}\text { Bisco Bio-science } \\
\text { (7) }\end{array}$ & Naya-940 (1) & $\begin{array}{l}\text { Bisco-Prince,Bisco-X-81, } \\
\text { Bisco-X97-Gold (3) }\end{array}$ & Bisco-X-92 (1) & $\begin{array}{l}\text { Bisco- } \\
\text { Bumper,Bisco- } \\
\text { Heera (2) }\end{array}$ \\
\hline $\begin{array}{l}\text { Bayer Bio-science } \\
\text { (6) }\end{array}$ & - & $\begin{array}{l}\text { Proagro-4642,Proagro- } \\
\text { Sampanna (2) }\end{array}$ & $\begin{array}{l}\text { LY-558,LY- } \\
\text { 597,Proagro- } \\
\text { 4640,Proagro-4794 } \\
\text { (4) }\end{array}$ & - \\
\hline CP Seeds (4) & - & - & - & $\begin{array}{l}\text { CP-666,CP-808, } \\
\text { CP-828,CP-838 }\end{array}$ \\
\hline $\begin{array}{l}\text { Delta Agri- } \\
\text { genetics (3) }\end{array}$ & - & $10 \mathrm{~V} 20(1)$ & - & 10V10,Chhabili \\
\hline $\begin{array}{l}\text { Dhaanya Seeds } \\
\text { (5) }\end{array}$ & $\begin{array}{l}\text { MM-1107,MM- } \\
\text { 1109,MM-7705 } \\
\text { (3) }\end{array}$ & - & DMH-7314 (1) & DMH-849 (1) \\
\hline Monsanto (9) & $\begin{array}{l}\text { 900-M- } \\
\text { Gold,Dekalb- } \\
\text { DK-984, Prabal } \\
\text { (3) }\end{array}$ & DKC-9081,Pinnacle (2) & $\begin{array}{l}\text { All-rounder,HiShell, } \\
\text { Super-900M (3) }\end{array}$ & Dekalb-Double \\
\hline Nath Bio-gene (4) & - & Big-Boss (1) & $\begin{array}{l}\text { Don-1588, Samrat- } \\
1144(2)\end{array}$ & Samrat-1133 (1) \\
\hline Pioneer HI (12) & 30B11,NMH-666 & NMH-1242,NMH-77, P- & 30V92,NMH-731,P- & NMH-909 (1) \\
\hline
\end{tabular}


Journal of Maize Research and Development (2016) 2 (1): 1-12

ISSN: 2467-9291 (Print), 2467-9305 (Online)

DOI: http://dx.doi.org/10.3126/jmrd.v2i1.16210

(2)

Shree Ram Bio-

seed (7)

Zuari Seed (5)
9681, Badshah-

Gold (2)
3404, P-3522, P-3540,P-

$3856(6)$

9220,Commando, Tx-369,

Rajkumar, Shaktiman, (5)

C-1921,C-1946,C-1950, -

6485 (4)

*Figure within bracket shows the number of hybrids

The group I comprehend the genotypes with greater mean rank value as well as higher $\mathrm{CV}$ percentage. The genotypes are high yielding but large variation in their performance. It indicates that the genotypes of this group perform better under favorable environment. For example, 11 hybrids of five seed companies (Table 5) and seven hybrids of four seed companies (Table 6) clustered under this group. The group II includes the genotypes having higher rank value and lower CV percentage. The genotypes of this group identified as good performing and stable. It means these genotypes are most desirable, high yielding as well as consistent over the locations. Twenty-five hybrids of nine seed companies and 22 hybrids of nine seed companies clustered under this group in respectively first and second year. In fact, the hybrids with the ability to good performance and adaptive characters might have clustered in this group.

Table 6: Genotype grouping based on coefficient of variation vs rank mean yield from 2011-12 data

\begin{tabular}{|c|c|c|c|c|}
\hline $\begin{array}{l}\text { Seed } \\
\text { companies }\end{array}$ & Group I (7) & Group II (22) & Group III (10) & Group IV (17) \\
\hline $\begin{array}{l}\text { Advanta Seeds } \\
(7)^{*}\end{array}$ & - & $\begin{array}{l}\text { Challenger, PAC-740,PAC- } \\
\text { 999, } \\
\text { Premier, Scorpio (5) }\end{array}$ & PAC-745 (1) & PAC-746 (1) \\
\hline $\begin{array}{l}\text { Bisco Bio- } \\
\text { Sciences (2) }\end{array}$ & - & Bisco-Jambo-65 (1) & Bisco-Moti-Delux (1) & - \\
\hline $\begin{array}{l}\text { Chand Hybrid } \\
\text { (5) }\end{array}$ & - & - & $907, C-745$ (2) & $\begin{array}{l}\text { 951-Supe, SC-719, } \\
\text { Top-Shell-957 (3) }\end{array}$ \\
\hline $\begin{array}{l}\text { Sichuan Deyue } \\
\text { Technology } \\
\text { (7) }\end{array}$ & & JM-1,JM-4,JM-6 (3) & JM-3(1) & $\begin{array}{l}\text { JM-2,JM-5, JM- } \\
7(3)\end{array}$ \\
\hline $\begin{array}{l}\text { Dhaanya seeds } \\
\text { (3) }\end{array}$ & $\begin{array}{l}\text { DHM- } \\
8255, \mathrm{MM}- \\
7529(2)\end{array}$ & - & MM-7659 (1) & - \\
\hline $\begin{array}{l}\text { Kirtiman Agro } \\
\text { Genetics (3) }\end{array}$ & - & $\begin{array}{l}\text { Kirtiman-Manik, } \\
\text { Kirtiman-Naresh (2) }\end{array}$ & - & $\begin{array}{l}\text { Kirtiman Kundan } \\
\text { (1) }\end{array}$ \\
\hline $\begin{array}{l}\text { Manisha Agri } \\
\text { Biotech (4) }\end{array}$ & & $\begin{array}{l}\text { Manisa-8181,Manisa-9292 } \\
\text { (2) }\end{array}$ & Manisa-7272(1) & Manisa-6363 (1) \\
\hline Monsanto (8) & $\begin{array}{l}\text { 900M-Gold, } \\
\text { Parbal (2) }\end{array}$ & - & - & $\begin{array}{l}\text { All-rounder, } \\
\text { Dekalb-Double, } \\
\text { DKC-9081, DKC- } \\
\text { 9120, Pinacle, } \\
\text { Super-900M(6) }\end{array}$ \\
\hline $\begin{array}{l}\text { Pioneer HI } \\
\text { Seeds(1) }\end{array}$ & - & P-3396 (1) & - & - \\
\hline Rasi Seeds (4) & - & $\begin{array}{l}\text { 3022, 3033,Tip-Top,Top- } \\
\text { Class (4) }\end{array}$ & - & - \\
\hline Namdhari & Bikas-666 (1) & - & Saurav-Flat, Tanishk & Pragati,Saurav- \\
\hline
\end{tabular}




\section{Journal of Maize Research and Development (2016) 2 (1): 1-12 \\ ISSN: 2467-9291 (Print), 2467-9305 (Online) \\ DOI: http://dx.doi.org/10.3126/jmrd.v2i1.16210}

Seeds (5)

Vibha Seeds

(7)
Eden-(VMH- Elite, MACVMH-4102,

4040), Legend Super-Hi-corn, ×-Paid(4)
(2)

Boom -(VMH-2015)

(1)
Round(2)

(2)

*Figure within bracket shows the number of hybrids

The group III comprised the genotypes having lower rank value as well as lower CV percentage. The genotypes are consistent but low yielding. Therefore, it is supposed to be the group of undesirable genotypes because of low yield performance across the environments. For example, 15 hybrids of seven seed companies in the first year and 10 hybrids of eight seed companies in the second year clustered under this group. The group IV consisted of genotypes with lower mean yield rank value but higher $\mathrm{CV}$ percentage. The genotypes of this group were inconsistent and low yielding. Therefore, it was the group of highly undesirable genotypes. For example, 18 genotypes of nine seed companies in the first year and seventeen hybrids of seven seed companies in the second year clustered under this group. In summary, the hybrids that clustered under group III and group IV might not be suitable to grow on eastern, central and inner Terai in Nepal.

\section{Superiority measures based on yield}

The name of potential high yielding and stable hybrids with the seed company, yield over locations and lower superiority value $(\mathrm{Pi})$ presented on table 7-8.

Table 7: List of good performing and stable maize hybrids based on superiority measures across the locations in 2010-11.

\begin{tabular}{|c|c|c|c|c|c|c|c|c|}
\hline \multirow[t]{2}{*}{ Seed company } & \multirow[t]{2}{*}{ Hybrid name } & \multicolumn{4}{|c|}{ Grain yield $\left(\mathrm{kg} \mathrm{ha}^{-1}\right)$} & \multirow[t]{2}{*}{ SD } & \multirow{2}{*}{$\begin{array}{l}\mathrm{CV}, \\
\%\end{array}$} & \multirow{2}{*}{$\begin{array}{l}\text { Superiori } \\
\text { ty } \\
\text { Measure } \\
\text { (Pi) }\end{array}$} \\
\hline & & Parwanipur & Rampur & Tarahara & $\begin{array}{c}\text { Mea } \\
\mathrm{n}\end{array}$ & & & \\
\hline \multirow{5}{*}{$\begin{array}{l}\text { Shree Ram Bio- } \\
\text { seed }(5)^{*}\end{array}$} & Shaktiman & 10157 & 8112 & 9195 & 8654 & 102 & 11.2 & 162.1 \\
\hline & $\mathrm{Tx}-369$ & 8440 & 10284 & 9560 & 9922 & 929 & 9.9 & 261.8 \\
\hline & Commando & 8094 & 8390 & 9986 & 9188 & 101 & 11.5 & 270.6 \\
\hline & 9220 & 7663 & 7849 & 9639 & 8744 & 109 & 13 & 338.1 \\
\hline & Rajkumar & 9443 & 6985 & 8476 & 7731 & 123 & 14.9 & 354.6 \\
\hline \multirow[t]{4}{*}{ PHI Seeds Pvt (4) } & P-3856 & 9546 & 11490 & 9541 & 1051 & 112 & 11 & 60.2 \\
\hline & P-3404 & 8832 & 7061 & 9903 & 8482 & 143 & 16.7 & 284.4 \\
\hline & P-3522 & 8924 & 8476 & 8391 & 8434 & 286 & 3.3 & 286.1 \\
\hline & P-3540 & 8856 & 7327 & 9019 & 8173 & 933 & 11.1 & 410.5 \\
\hline \multirow[t]{4}{*}{ Zuari Seed Ltd.(4) } & C-1950 & 9725 & 8668 & 8024 & 8346 & 859 & 9.8 & 229.9 \\
\hline & C-1946 & 7903 & 8537 & 11654 & 1009 & 200 & 21.4 & 250.8 \\
\hline & C-6485 & 8881 & 6758 & 8041 & 7399 & 106 & 13.5 & 452.5 \\
\hline & C-1921 & 9553 & 5913 & 7943 & 6928 & 182 & 23.4 & 470.6 \\
\hline \multirow{3}{*}{$\begin{array}{l}\text { Bisco Bio-science } \\
\text { (3) }\end{array}$} & Bisco-X97-Gold & 7218 & 11704 & 9368 & 1053 & 224 & 23.8 & 203.3 \\
\hline & Bisco-X-81 & 7976 & 8913 & 7851 & 8382 & 581 & 7 & 444.8 \\
\hline & Bisco-Prince & 10713 & 8725 & 8801 & 8763 & 112 & 12 & 105.1 \\
\hline \multirow{4}{*}{$\begin{array}{l}\text { Bayer Bio-science } \\
\text { (2) } \\
\text { Monsanto Ltd. (2) }\end{array}$} & Proagro- & 8906 & 8770 & 7953 & 8361 & 516 & 6 & 313.1 \\
\hline & Proagro-4642 & 9567 & 8249 & 7679 & 7964 & 969 & 11.4 & 359.2 \\
\hline & Pinnacle & 9473 & 7501 & 10716 & 9108 & 162 & 17.6 & 259.9 \\
\hline & DKC-9081 & 9119 & 7282 & 8699 & 7991 & 962 & 11.5 & 416.7 \\
\hline \multirow{2}{*}{$\begin{array}{l}\text { Nuziveedu } \\
\text { (2) }\end{array}$} & NMH-1242 & 7886 & 9325 & 10709 & 1001 & 141 & 15.2 & 216 \\
\hline & NMH-777 & 8233 & 7919 & 8439 & 8179 & 262 & 3.2 & 451.9 \\
\hline
\end{tabular}


Journal of Maize Research and Development (2016) 2 (1): 1-12

ISSN: 2467-9291 (Print), 2467-9305 (Online)

DOI: http://dx.doi.org/10.3126/jmrd.v2i1.16210

\begin{tabular}{|c|c|c|c|c|c|c|c|c|c|}
\hline Aishwarya & Seed & TCS-9696 & 9479 & 7224 & 10515 & 8869 & 168 & 18.6 & 258.1 \\
\hline $\begin{array}{l}\text { Delta } \\
\text { genetics (1) }\end{array}$ & Agri- & $10 \mathrm{~V} 20$ & 8218 & 7353 & 9703 & 8528 & $\begin{array}{c}118 \\
9\end{array}$ & 14.1 & 378.1 \\
\hline Nath Bio-ge & ne $(1)$ & Big-Boss & 8645 & 7846 & 8146 & 7996 & 403 & 4.9 & 422.3 \\
\hline
\end{tabular}

*Figure within bracket shows the number of hybrids

The genotypes having lower superiority measure $(\mathrm{Pi})$ value also showed higher mean yield and lower coefficient of variation. The genotypes with more than $8000 \mathrm{~kg} \mathrm{ha}^{-1}$ grain yields and least standard deviation are P3522, Biscox81, Proagro Sampanna, and NMH777 in the first year and more than $7000 \mathrm{~kg} \mathrm{ha}^{-1}$ grain yield and smallest standard deviation are Challenger, Top Class, MAC (VMH4102) and Super Hi-corn in the second year. Table 7-8 also include the lists of same varieties on group II in table 5 where 25 hybrids of 10 seed companies and 22 hybrids of eight seed companies produced good yield performance and stability respectively in the first and second year. In summary, P3856 of Pioneer, as well as Bisco prince of Bisco bio-science in the first year (Table 7) and 3022 of Rashi seed as well as Kritiman Manik of Kritiman agro in the second year (Table 8) was the top performing and stable hybrids. The results also showed that the same variety of Monsanto failed to produce similar yield on next season experiment in comparison to the first season. The hybrids from Dhaanya seed could not meet the criteria for both the years. Likewise, none of the varieties of CP seed, Namdhari seeds and Chand Hybrid able to show stability and good yield performance. The seed companies generating more numbers of competitive hybrids were Pioneer, Shree Ram, and Advanta followed by Bisco Bioscience, Vibha, and Zuari.

Table 8. List of good performing and stable maize hybrids based on superiority measures across locations in 2011-12.

\begin{tabular}{|c|c|c|c|c|c|c|c|c|}
\hline \multirow[t]{2}{*}{ Seed company } & \multirow[t]{2}{*}{ Hybrid name } & \multicolumn{4}{|c|}{ Grain yield $\left(\mathrm{kg} \mathrm{ha}^{-1}\right)$} & \multirow[t]{2}{*}{ SD } & \multirow{2}{*}{$\begin{array}{l}\text { CV } \\
(\%)\end{array}$} & \multirow{2}{*}{$\begin{array}{l}\text { Superiorit } \\
\mathrm{y} \\
\text { Measure } \\
\text { (Pi) based }\end{array}$} \\
\hline & & $\begin{array}{c}\text { Parwanip } \\
\text { ur }\end{array}$ & $\underset{r}{\text { Rampu }}$ & $\begin{array}{c}\text { Tarahar } \\
\text { a }\end{array}$ & $\begin{array}{c}\text { Mea } \\
\mathrm{n}\end{array}$ & & & \\
\hline \multirow[t]{5}{*}{ Advanta Ltd (5)* } & Scorpio & 8516 & 6304 & 7829 & 7550 & 113 & 15 & 101.1 \\
\hline & Challenger & 7679 & 6577 & 6824 & 7027 & 578 & 8.2 & 145.9 \\
\hline & Premier & 8380 & 7658 & 5951 & 7330 & 124 & 17 & 154.5 \\
\hline & PAC-740 & 8290 & 6638 & 5372 & 6767 & 146 & 21. & 216.5 \\
\hline & PAC-999 & 8998 & 5857 & 4895 & 6583 & 214 & 32. & 251.0 \\
\hline \multirow{4}{*}{ Rashi seed (4) } & 3022 & 9322 & 7370 & 8442 & 8378 & 977 & 11. & 20.0 \\
\hline & Top-Class & 8260 & 7957 & 7772 & 7996 & 246 & 3.1 & 65.8 \\
\hline & Tip-Top & 8871 & 7440 & 6625 & 7645 & 113 & 14. & 103.2 \\
\hline & 3033 & 6413 & 6681 & 7135 & 6743 & 365 & 5.4 & 205.1 \\
\hline Agri-tech & (VMH- & 7717 & 8202 & 7523 & 7814 & 350 & 4.5 & 99.9 \\
\hline & Super-Hi-corn & 7246 & 6498 & 7670 & 7138 & 593 & 8.3 & 139.1 \\
\hline & Elite-(VMH- & 7425 & 5370 & 8396 & 7064 & 154 & 21. & 170.0 \\
\hline & X-Paid & 7358 & 4341 & 7389 & 6363 & 175 & 27. & 333.2 \\
\hline Sichuan & JM-4 & 6330 & 7545 & 5958 & 6611 & 830 & 12. & 257.5 \\
\hline Tech & JM-6 & 5768 & 6784 & 6796 & 6450 & 590 & 9.2 & 282.7 \\
\hline Seeds (3) & JM-1 & 7253 & 5332 & 6180 & 6255 & 963 & 15. & 315.1 \\
\hline \multirow[t]{2}{*}{ Kritiman Agro (2) } & Kirtiman-Manik & 8100 & 7304 & 9566 & 8323 & 114 & 13. & 36.0 \\
\hline & Kirtiman-Nares & 5936 & 5027 & 7280 & 6081 & 113 & 18. & 352.8 \\
\hline \multirow{2}{*}{ Manisha Agro (2) } & Manisa-9292 & 9207 & 6008 & 5130 & 6782 & 214 & 31. & 219.9 \\
\hline & Manisa-8181 & 7403 & 6269 & 4841 & 6171 & 128 & 20. & 308.3 \\
\hline
\end{tabular}


Journal of Maize Research and Development (2016) 2 (1): 1-12

ISSN: 2467-9291 (Print), 2467-9305 (Online)

DOI: http://dx.doi.org/10.3126/jmrd.v2i1.16210

$\begin{array}{lllllllll}\text { PHI Seeds Pvt (1) } & \text { P-3396 } & 9875 & 8120 & 6217 & 8070 & 183 & 22 . & 112.7\end{array}$

$\begin{array}{lllllllll}\text { Bisco Bio-science } & \text { Bisco-Jambo-65 } & 7911 & 5476 & 7595 & 6994 & 132 & 18 . & 155.6\end{array}$

*Figure within bracket shows the number of hybrids

\section{DISCUSSION}

The existing heterogeneity among the evaluated hybrids and growing environment clearly reflected on days to silking, plant height, and grain yield performance of commercial hybrid maize. In general, maize experience severe cold stress during the flowering time when planted in winter. The silking period is the most sensitive period for the crop when maize planted in cold stress condition (Abendroth et al., 2011). Silking duration was quite long in winter maize because of low temperature and low solar radiation in Terai. The time required for corn to progress from vegetative to the reproductive stage is based on the amount of heat accumulated (Abendroth et al., 2011; Thomison \& Nielson, 2002). Cold stress during flowering time directly affects silking time rather than anthesis, which increases the gap between anthesis and silking, obstructs fertilization, and ultimately reduce the kernel number per ear. The differences in grain yield across environments might be owing to variation in the genetic base of the hybrids, differing environmental conditions over sites, and GEI. Similar kind of observation was also reported by Sharma et al. (2008). The maize hybrids developed by different seed companies with various genetic backgrounds might be the major causes of variability in performance among genotypes. Shrestha and Kunwar (2014) from two years observation recorded that there was significant variation in eighteen maize hybrids for flowering and grain yield. The variation in climatic parameters and soil type of experimental site might be also depicted on the performance of these commercial hybrids. Growth and development of crops influenced by temperature, radiation, photoperiod and water availability (Tsimba et al., 2013). Furthermore, Parwanipur followed by Tarahara was the highest grain yield producing sites in both the years. It also showed that maize growing environment of Rampur was closer to both Parwanipur and Tarahara. A similar kind of result was also reported by Koirala et al. (2013). The effect of GEI was high on final harvest of commercial hybrids that's why the same genotype behaves differently on changed location. Four distinct groups of genotypes were observed from this distribution pattern analysis. The mean-CV method for genotype grouping was used on yield stability analysis on hybrid maize (Francis \& Kannenberg, 1978). Altogether, forty-seven hybrids of twenty seed companies with higher rank value and lower $\mathrm{CV}$ percentage were identified as good performing and stable. In the meantime, a large yield variation explained by environments and GEI than genotype indicates that environment and GEI factors were vital than genotype in crop yield. The stable and high yielding genotypes can be suitable for general cultivation to wider regions. In addition to this, those genotypes which are performing better yield on specific location could be suitable for cultivation to a particular region. Superiority measure helps to measure the behavior of genotypes where genotype $\times$ environment interactions is significant (Lin \& Binns, 1988).

\section{CONCLUSION}

The increasing numbers of new seed companies on testing of new hybrids with enough numbers of competitive varieties revealed the future potentiality of hybrid seed marketing in Nepal. Those commercial hybrids which had high yield potential and stable could be suitable for general cultivation to similar environments. However, genotypes with better yield performance 
Journal of Maize Research and Development (2016) 2 (1): 1-12

ISSN: 2467-9291 (Print), 2467-9305 (Online)

DOI: http://dx.doi.org/10.3126/jmrd.v2i1.16210

on certain location could be suitable to grow only on that specific region. Furthermore, among the three locations, Parwanipur identified as high yielding site and Rampur as a representative site for hybrid evaluation in both years. Pioneer, Shree Ram, and Advanta followed by Bisco Bio-science, Vibha, and Zuari are recognized as the seed companies producing more numbers of competitive hybrids.

\section{ACKNOWLEDGEMENTS}

The authors express sincere thanks to commercial seed companies for genetic materials and financial support in this study. The research team of NMRP, Rampur; RARS, Parwanipur; and RARS, Tarahara are gratefully acknowledged for trial management and data recording. All personages who provided valuable feedback and suggestions on this paper are also appreciated.

\section{REFERENCES}

Abendroth, L. J., Elmore, R., Boyer, M., \& Marlay, S. (2011). "Corn growth and development," Iowa State University, University Extension.

Adhikari, J. (2014). Seed sovereignty: Analysing the debate on hybrid seeds and GMOs and bringing about sustainability in agricultural development. Journal of Forest and Livelihood 12, 33-46.

Alvarado, G., Lopez, M., Vargas, M., Pacheco, A., Rodríguez, F., Burgueño, J., \& Crossa, J. (2015). META-R (Multi Environment Trial Analysis with R for Windows) Version 5.0 http://hdl.handle.net/11529/10201">hdl:11529/10201</a〉 International Maize and Wheat Improvement Center [Distributor]V13 [Version].

CDD. (2013). Crop Division Directoriate. Impact of maize mission program. http://cddnepal.gov.np/uploaded/Impact_Maize_Mission_Program.pdf.

Dhakal, S. C., Regmi, P. P., Thapa, R. B., Sah, S. K., \& Khatri-Chhetri, D. B. (2015). Productivity and profitability of maize-pumpkin mix cropping in Chitwan, Nepal. Journal of Maize Research and Development, 1, 112-122.

Francis, T., \& Kannenberg, L. (1978). Yield stability studies in short-season maize. I. A descriptive method for grouping genotypes. Canadian Journal of Plant Science, 58, 1029-1034.

Gurung, D. B., Upadhyay, S. R., Pandey, B. R., Pokhrel, B. B., \& Kshetri, J. B. (2011). Hybrid maize seed production: A new initiative for reliable and sustainable hybrid maize seed supply in Nepal. Agriculture Development Journal, 8, 1-8.

Heisey, P. W., Morris, M. L., Byerlee, D., \& Lopez-Pereira, M. A. (1998). Economics of hybrid maize adoption. In Morris, M.A. (ed.). Maize seed industries in developing countries. Boulder, Colorado, Lynne Reinner.

Koirala, K. B., Gurung, D. B., Kunwar, C. B., Tripathi, M., Thakur, P., Bhandari, G., Bhandari, B., Shrestha, J., Karki, T. B., Baral, B. R., Adhikari, P., Achhami, B. B., BK, S. B., Bhurer, K. P., Chaudhary, B. N., \& Chhetri, J. B. (2013). Evaluation of multinational companies' maize hybrids during winter season of 2010-2012. Proceedings of the 27th National Summer Crops Workshop 2.

Lin, C. S., \& Binns, M. R. (1988). A superiority measure of cultivar performance for cultivarx location data. Canadian Journal of Plant Science, 68, 193-198. 
MacRobert, J. F., Setimela, P. S., Gethi, J., \& Worku, M. (2014). Maize Hybrid Seed Production Manual. Mexico,D.F.:CIMMYT.

Ransom, J. K., Paudyal, K. \& Adhikari, K. (2003). Adoption of improved maize varieties in the hills of Nepal. Agricultural Economics, 29, 299-305.

Sharma, D., Sharma, R. C., Dhakal, R., Dhami, N. B., Gurung, D. B., Katuwal, R. B., Koirala, K. B., Prasad, R. C., Sah, S. N., Upadhyay, S. R., Tiwari, T. P., \& Ortiz-Ferrara, G. (2008). Performance stability of maize genotypes across diverse hill environments in Nepal. Euphytica, 164, 689-698.

Shrestha, J., \& Kunwar, C. B. (2014). Evaluation of original and selected maize populations for agronomic traits under mass selection. Scrutiny International Research Journal of Agriculture, Plant Biotechnology and Bio Products, 1, 1-11.

Thapa, M. (2013). Regulatory framework of GMOs and hybrid seeds in Nepal. Agronomy Journal of Nepal, 3, 128-138.

Thomison, P., \& Nielson, R. (2002). Impact of delayed planting on heat unit requirements for seed maturation in maize. Pontificia Universidad Católica de Chile. Departamento de Ciencias Vegetales. Seminario Internacional Semillas: comercialización producción y tecnología. Santiago, 15, 140-164.

Tsimba, R., Edmeades, G. O., Millner, J. P., \& Kemp, P. D. (2013). The effect of planting date on maize: Phenology, thermal time durations and growth rates in a cool temperate climate. Field Crops Research, 150, 145-155.

Ye, G., McNeil, D., \& Hill, G. (2001). Methods for analysing multi-site plant variety trials. II. Selection for yield and stability. Agronomy New Zealand, 31, 25-33. 